The pl ant fossi I s from the Kai zar a For mat i on (Cal I ovi an, Jur assi c) of the Tet ori Group in the I zum di strict, Fukui pref ecture, Central Japan

\begin{tabular}{|l|l|}
\hline 著者 & Yamada Toshi hi ro, Uemur a Kazuhi ko \\
\hline $\begin{array}{l}\text { j our nal or } \\
\text { publ i cat i on t i t l e }\end{array}$ & Pal eont ol ogi cal Resear ch \\
\hline vol une & 12 \\
\hline number & 1 \\
\hline page r ange & $1-17$ \\
\hline year & 2008 04 30 \\
\hline URL & ht t p: //hdl . handl e. net /2297/14544 \\
\hline
\end{tabular}




\title{
The plant fossils from the Kaizara Formation (Callovian, Jurassic) of the Tetori Group in the Izumi district, Fukui Prefecture, Central Japan
}

\author{
TOSHIHIRO YAMADA ${ }^{1}$ AND KAZUHIKO UEMURA ${ }^{2}$ \\ ${ }^{1}$ Division of Life Sciences, Graduate School of Natural Science and Technology, Kanazawa University, Kanazawa 920-1192, Japan \\ (e-mail:ptilo@mb.infoweb.ne.jp) \\ ${ }^{2}$ Department of Geology and Paleontology, National Museum of Nature and Science, 3-23-1 Hyakunincho, Shinjuku-ku, Tokyo 169-0073, Japan
}

Received December 5, 2006; Revised manuscript accepted October 10, 2007

\begin{abstract}
The Middle Jurassic (Bathonian to Callovian) Kaizara flora is proposed herein for the plant fossil assemblage in the Kaizara Formation, Kuzuryu Subgroup, Tetori Group. In addition to Otozamites crassipinnatus sp. nov., twelve species are reported, including species of Equisetales, uncertain order of pteridosperms, Cycadeoideales, Cycadales, and Coniferales. Some species have very thick lamina, implying that the climate might include dry periods. All species found in the Kaizara flora are new to the Tetori Group. Therefore, the Tetori-type flora is restricted to post-Callovian stages in the Tetori Group.
\end{abstract}

Key words: Kaizara flora, Kaizara Formation, Kuzuryu Subgroup, Tetori Group, Middle Jurassic, Tetoritype flora

\section{Introduction}

The Tetori Group is a series of Middle Jurassic to Lower Cretaceous formations which is widely distributed over the Hida Belt in northern Central Japan (Figure 1A). The group consists of marine and nonmarine deposits and is subdivided into three subgroups which are dated roughly as follows; the Kuzuryu Subgroup is Bathonian to Kimmeridgian, the Itoshiro Subgroup is Tithonian to Barremian, and the Akaiwa Subgroup is post-Barremian, based on the ages of the marine invertebrates in some of the constituent formations (Maeda, 1961a; Sato and Westermann, 1991; Fujita, 2003; Sato et al., 2003; Sato and Yamada, 2005; Matsukawa et al., 2006; Goto, 2007).

Since Geyler (1877) first reported plant fossils from it, many paleobotanical studies have been conducted in the Tetori Group (e.g., Yokoyama, 1889; Oishi, 1940; Kimura, 1958; Kimura et al., 1978). Four floras are reported in the Tetori Group, namely, the Bathonian to Callovian Kuzuryu flora in the Kuzuryu Subgroup (Kimura, 1958), Tithonian to Barremian Oguchi flora in the Kuwajima Formation of the Itoshiro Subgroup (Kimura et al., 1978; Yabe et al., 2003), Barremian Akaiwa flora in the Akaiwa Formation of the Akaiwa
Subgroup (Kimura and Sekido, 1976b; Yabe et al., 2003), and Barremian Tamodani flora in the Chinaboradani Formation of the Akaiwa Subgroup (Kimura, 1975; Yabe et al., 2003). These floras are similar to each other in species composition, including various pteridophytes and ginkgophytes, and are further classified as Tetoritype (or Siberian) floras, which flourished under a humid warm-temperate climate (Kimura, 1987; Vakhrameev, 1991).

Among them, the Kuzuryu flora, that is, the oldest one, has been used as a basis for inferring the paleophytogeography and paleoclimates during Middle Jurassic time in Japan (Kimura, 1987; Vakhrameev, 1991). However, almost all horizons bearing the Kuzuryu flora have been reassigned to post-Callovian formations in recent studies (Figure 2; for details, see the next section). Besides the Kuzuryu flora, only one other purportedly Middle Jurassic flora was known from Japan, namely, the Utano flora in the Utano Formation of the Toyora Group in Yamaguchi Prefecture in western Honshu (Takahasi et al., 1965; Kimura et al., 1986; Kimura and Ohana, 1987a). Recent reexamination of the stratigraphy of the plant-bearing deposits (Yamada and Ohno, 2005) has shown that the Utano Flora actually occurs from the Upper Jurassic to lowermost Cretaceous 


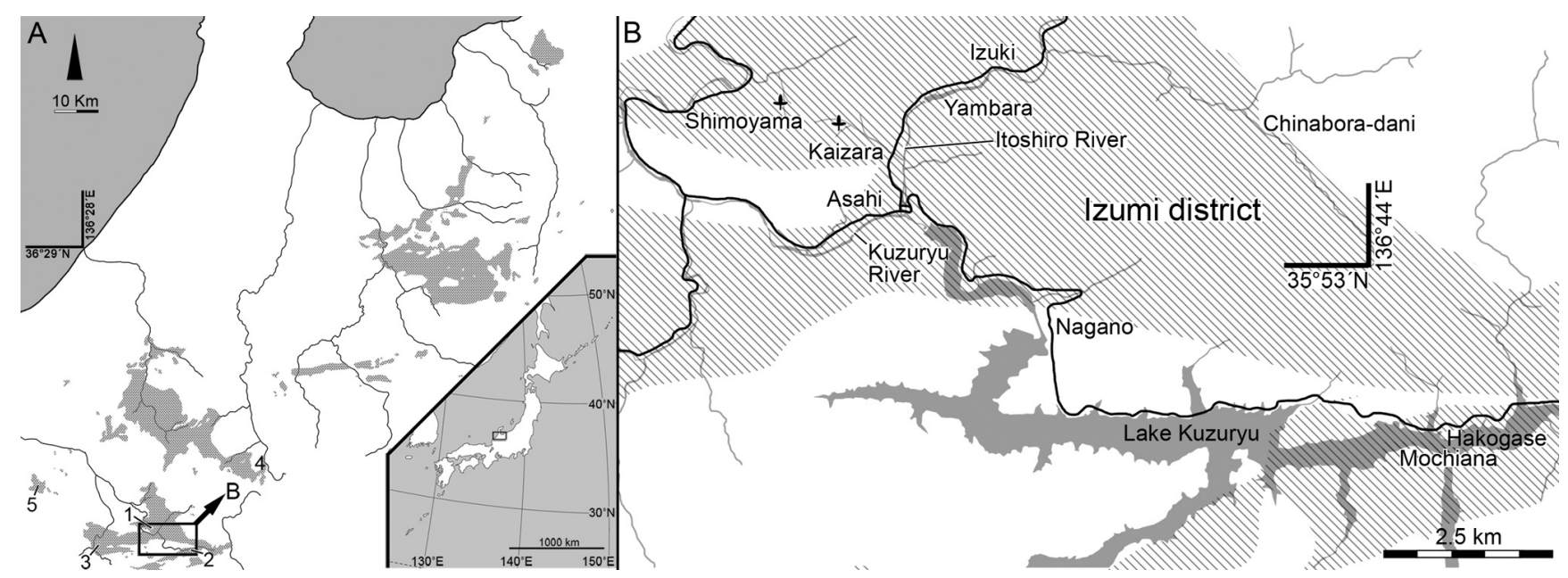

Figure 1. A. Distribution of the Tetori Group (after Maeda, 1961b) indicated by shading. Numbers indicate localities of "Middle" Jurassic plant assemblages: 1. Shimoyama area, Ohno City, Fukui Pref., 2. Hakogase and Mochiana areas, Ohno City, 3. Wakogo area, Ohno City, 4. Ushimaru area, Takayama City, Gifu, Pref., 5. Asuwa region, Fukui City, Fukui Pref. B. Magnification of boxed area in A. The type localities of the Kaizara flora are indicated by the leaflet marks.

(Berriasian) Kiyosue Formation of the Toyonishi Group. Therefore, as far as previous reports are concerned, no true Middle Jurassic flora is known in Japan.

Here, we will report some plant fossils from the Bathonian-Callovian Kaizara Formation of the Kuzuryu Subgroup, found in the Izumi district of Ohno City, Fukui Prefecture (Figure 1B). This is the first reliable report of a Middle Jurassic flora from Japan. A new name, Kaizara Flora, is given to this flora and its stratigraphic significance will be discussed. Paleophytogeography of Middle Jurassic Japan is also inferred.

\section{Previous and current stratigraphy in localities bearing the Kuzuryu flora}

The Kuzuryu flora was firstly defined as the plant fossil assemblages of the Kuzuryu Subgroup and type localities were designated in the Hakogase, Mochiana, Shimoyama, Ushimaru and Wakogo areas (Kimura, 1958; Figures 1A.1-4, 1B, 2). After the proposal of the Kuzuryu flora, plant fossil assemblages of the Sakaidera and Kowashimizu formations in the Asuwa region (Figures 1A.5,2) were considered as coevals of the Kuzuryu flora (Maeda, 1961a). The previous and current status of the stratigraphy in these localities is discussed below.

\section{Shimoyama area in Kuzuryu / Itoshiro region (Figure 1A.1)}

The type section of the Kuzuryu and Itoshiro Subgroups is designated in the Kuzuryu / Itoshiro region. The Kuzuryu Subgroup in the type region is composed of the Shimoyama, Oidani, Tochimochiyama, Kaizara and Yambarazaka formations in ascending order (Maeda, 1961a; Fujita, 2003; Figure 2). These consist of marine deposits except for the lowermost Shimoyama Formation (Maeda, 1961a; Fujita, 2003). The ages of the Kaizara and Yambarazaka formations are well constrained by ammonoids, namely, late Bathonian to Callovian for the former and Oxfordian to early Kimmeridgian for the latter (Sato and Westermann, 1991).

Recent studies basically follow this stratigraphy and the dating of the formations (Fujita, 2002, 2003; Matsukawa et al., 2006), although the Oidani Formation is included in the Tochimochiyama Formation in Matsukawa et al. (2006). Otozamites sewardii, a component of the Kuzuryu flora, is reported from the Kaizara Formation distributed in the Shimoyama area by Oishi (1940). This is the only component of the Kuzuryu flora which has actually been collected from these Middle Jurassic deposits (Figure 2).

\section{Hakogase and Mochiana areas in East of Izumi re- gion (Figure 1A.2)}

The Mochiana, Ochiai and Shimohambara Formations comprised the Kuzuryu Subgroup in this region (Maeda, 1956, 1961a). The Shimohambara Formation was correlated to the Yambarazaka Formation using Inoceramus sp. and Perisphinctes sp. (Maeda, 1961a). The plantbearing horizons of the Hakogase and Mochiana areas were placed in the Ochiai Formation which underlies the Shimohambara Formation, thus a pre-Oxfordian age for the plant fossils was suggested (Figure 2). 


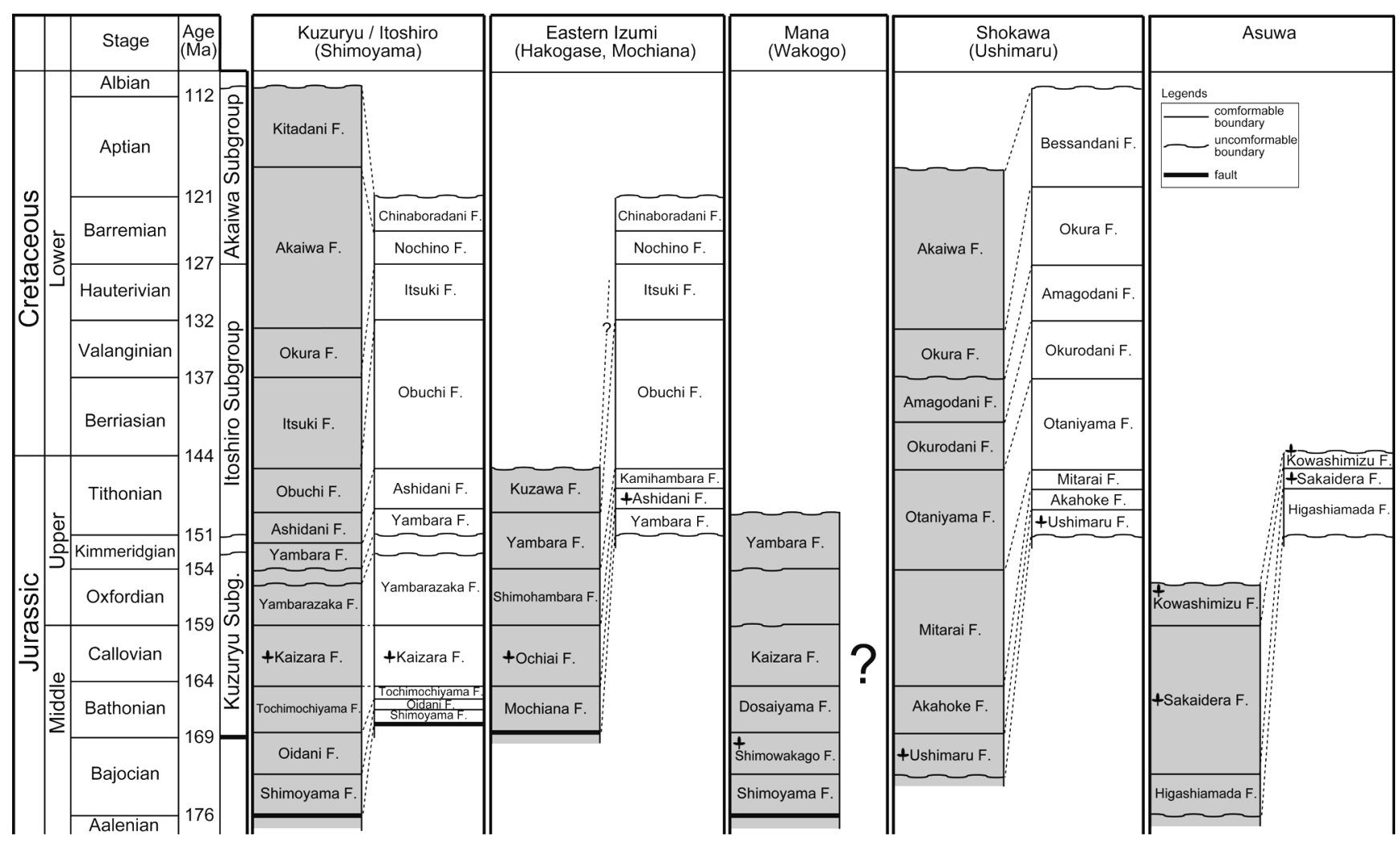

Figure 2. Previous and current interpretations on stratigraphic horizons bearing "Kuzuryu" flora (see text for references on these interpretations). Previously accepted stratigraphic schemes are shaded. Corresponding formational boundaries between two interpretations are correlated by dashed lines. Formations bearing "Kuzuryu" flora are indicated by leaflet marks.

Recently, in a comprehensive stratigraphic study that encompassed the Kuzuryu/Itoshiro and East of Izumi regions (Fujita, 2002; Matsukawa et al., 2006) has shown that only the Itoshiro Subgroup is distributed in this region. Fujita (2002) reassigned the plant-bearing horizons to the Ashidani Formation and redefined the overlying marine Shimohambara Formation as the Kamihambara Formation. A Tithonian age for the Ashidani Formation is deduced (Figure 2) because the underlain Yambara Formation is post-Kimmeridgian in age (Sato and Westermann, 1991; Fujita, 2003), while the occurrence of Parapallasiceras sp. cf. pseudocontiguum (Donze and Enay) suggests a late Tithonian age for the overlying Kamihambara Formation (Sato and Yamada, 2005).

Matsukawa et al. (2006) assigned the plant-bearing horizons and overlying marine sediments to the Itsuki Formation, but this assignment is not concomitant with the report of an ammonoid of the family Crioceratitidae from the Itsuki Formation, which rather indicates a late Hauterivian to Barremian age (Goto, 2007).

\section{Wakogo area in Mana region (Figure 1A.3)}

The Kuzuryu Subgroup in the region consisted of the Shimoyama, Shimowakago, Dosaiyama and Kaizara Formations in ascending order (Maeda, 1960; Figure 2). Ammonoid-bearing deposits were assigned to the Kaizara Formation, which is a stratigraphic unit originally defined in the Kuzuryu/Itoshiro region. Plantbearing horizons were arranged into the Shimowakago Formation, which was considered to underlie the Kaizara Formation (Maeda, 1960, 1961a; Figure 2).

In the previous stratigraphy, the ammonoid-bearing deposits were assigned to the Kaizara Formation on the assumption that the deposits were isochronal to the Kaizara Formation (Maeda, 1960), although none of the ammonoids have been identified thus far by genera or species. To the contrary, the existence of upper Tithonian marine deposits in the Mana region has been hinted at recently by the occurrence of Parapallasiceras sp. cf. pseudocontiguum (T. Sato, personal communication). Therefore, reexamination of the ammonoids from the marine sediments in the Mana region would be required before reconstructing the stratigraphy in this region. 
Yamada et al. (1989) pointed out that Maeda (1960) interpreted the formational order in reverse, overlooking the fact that the strata are inclined more than $90^{\circ}$ (inverted) in this region. Thus, it is obvious that the plant-containing horizons are younger than the marine sediments, i.e., at least younger than the Callovian (Yamada et al., 1989).

\section{Ushimaru area in Shokawa region (Figure 1A.4)}

The Kuzuryu Subgroup in the Shokawa region was composed of the Ushimaru, Akahoke and Mitarai Formations in ascending order (Maeda, 1952, 1961a). Among them, the Mitarai Formation is a marine unit from which Lilloetia sp., indicating a Callovian age, was obtained (Sato and Kanie, 1963). The Ushimaru Formation contains plant fossils and their age was considered to be older than the Callovian (Maeda, 1961a; Figure 2).

Recently, a late Tithonian to Berriasian age for the Mitarai Formation has been suggested based on the occurrence of Delphinella sp. cf. obtusenodosa (Retowski) and the misidentification of Lilloetia sp., which was the basis for the Callovian date, pointed out by Sato et al. (2003). Accordingly, the Mitarai Formation is correlated to the Kamihambara Formation and all the Tetori Group formations in the Shokawa region are placed in the Itoshiro Subgroup (Sato and Yamada, 2005; Figure 2). Furthermore, much younger ages (younger than late Hauterivian) for the Ushimaru, Akahoke and Mitarai formations are suggested by zircon $\mathrm{U}-\mathrm{Pb}$ dating of tuff beds (Kusuhashi et al., 2006).

\section{Sakaidera and Kowashimizu Formations (Figure 1A.5)}

Plant-bearing horizons in the Asuwa region initially were treated as the Itoshiro Subgroup (Kimura, 1958). Later, Maeda (1961b) classified the Tetori Group sediments in the region into the Higashiamata, Sakaidera and Kowashimizu formations in ascending order, of which the Sakaidera and Kowashimizu Formations bear abundant plant fossils (Oishi, 1940; Maeda, 1961b; Figure 2). On the basis of unclassified ammonoids from river floats, the uppermost Kowashimizu Formation was compared to the Yambarazaka Formation (Maeda, 1961a, b). The Sakaidera Formation was correlated to the Mitarai Formation of the Shokawa area based on intercalated acidic tuffaceous beds (Maeda, 1961b). The Sakaidera Formation was, in turn, correlated to the Kaizara Formation because the Mitarai Formation was compared to the Kaizara Formation at that time (Maeda, 1961a, b).

If the acidic tuffaceous beds in the Sakaidera and Mitarai Formations are actually comparable, the Sakaidera Formation is partly isochronal to the Mitarai Formation, for which a late Tithonian to Berriasian age is inferred (Sato et al., 2003). Another line of evidence, the chemical compositions of monazite and garnet particles in sandstones, suggests that the three formations are included in the Itoshiro Subgroup (Yamada et al., 2005; Figure 2).

\section{Summary of the updated stratigraphy and its impli- cations on the Kuzuryu flora}

The Kuzuryu flora was originally defined as the flora of the Kuzuryu Subgroup, but all components of the Kuzuryu flora were actually collected from the Itoshiro Subgroup (Figure 2), except for Otozamites sewardii which was reported from the Bathonian to Callovian Kaizara Formation in the Shimoyama area by Oishi (1940). Although the Kuzuryu flora thus includes at least one species collected from the Kuzuryu Subgroup, it is not even certain at this point whether the same flora flourished continuously in the entire timespan of the Kuzuryu Subgroup, ranging from the Bathonian to Kimmeridgian (Sato and Westermann, 1991). Therefore, a new floristic name for the plant fossil assemblage of the Kaizara Formation is called for. Accordingly the name Kaizara flora is given to this assemblage.

\section{Materials and methods}

Plant fossils were collected from the siltstone beds in the Kaizara Formation (Kuzuryu Subgroup) at two localities in Izumi district, Ohno City; Horadani (Hora valley) at Kaizara area and Taniyamadani (Taniyama valley) at Shimoyama area (Figure 1B). The geological age of the Kaizara Formation is precisely determined as latest Bathonian to early Callovian (Sato, 1962; Sato and Westermann, 1991). All specimens are stored in the National Museum of Nature and Science, Tokyo.

\section{Taxonomy \\ Class Sphenopsida \\ Order Equisetales \\ Family Equisetaceae \\ Genus Equisetites Sternberg, 1833 Equisetites sp.}

Specimen.-NSM-PP-9912 (Figure 3A)

Locality.-Horadani, Kaizara area.

Description.-A single fragment of stem was collected, consisting of two nodes and the internode between them, which is compressed laterally. The internode is $2 \mathrm{~cm}$ long and $1.4 \mathrm{~cm}$ wide, and the surface is smooth. The nodes are slightly swollen to $1.6 \mathrm{~cm}$ wide. Leaf sheathes are $6 \mathrm{~mm}$ long and their lower two-thirds is 

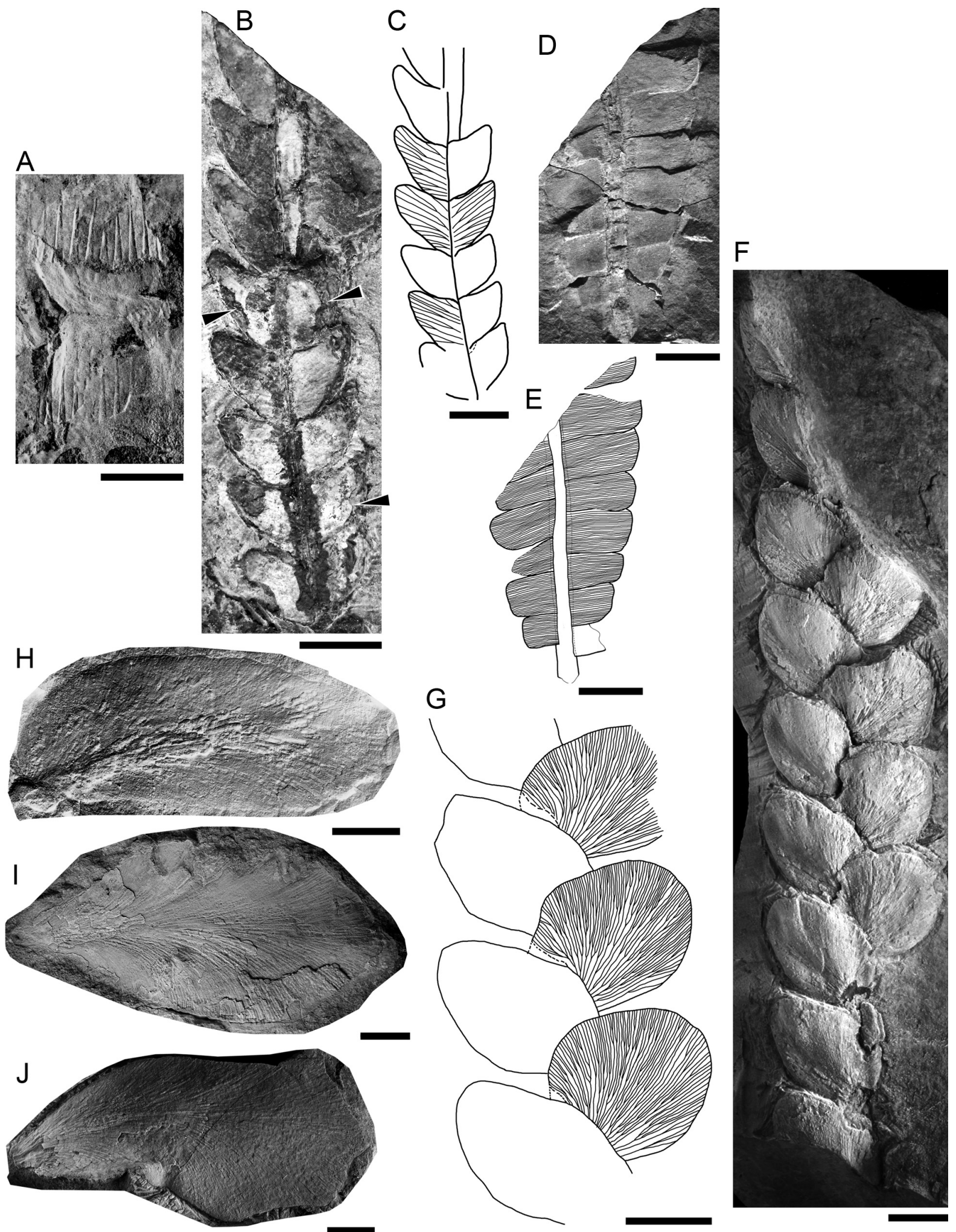

Figure 3. A. Equisetites sp., NSM-PP-9912. B. Ctenozamites usnadzei Doludenko et Svanidze, NSM-PP-9903. Arrowheads show remaining charred fragments of thick lamina. C. Line drawing of B. D. Anomozamites sp., NSM-PP-9917. E. Line drawing of D. F-J. Otozamites crassipinnatus Yamada and Uemura, sp. nov. F. Holotype, NSM-PP-9914. G. Line drawing of F. H. Paratype, NSM-PP-9916. I. Paratype, NSM-PP-9920. J. Paratype, NSM-PP-9915. Scale bars $=1 \mathrm{~cm}$. 
hardly distinguishable from the node. 9-10 leaf tooth segments dissected from the sheath are visible in the compressed specimen, thus it is probable that there are more than 18-20 segments around the node. The segments are separated by depressed commissural flanges and the base of the segments is much broader than the adjacent two flanges (ca. $0.8 \mathrm{~mm}$ wide). The segments are 5-10 mm long.

Comparison.-The specimen is assignable to genus Equisetites because it has leaf sheathes and its stem is smooth in the internode (Harris, 1961a). However, it could not be classified down to species level because information on the nodal diaphragm and the exact number of leaf tooth segments, which are inevitable for making the specific assignment, are lacking.

\section{Class Pteridospermopsida \\ Order uncertain \\ Family uncertain}

Genus Ctenozamites Nathorst, 1886

Ctenozamites usnadzei Doludenko et Svanidze, 1969

Ctenozamites usnadzei Doludenko et Svanidze, 1969, p. 24, pl. 18, figs. 1-6; pl. 19, figs. 3, 5, 6; Barnard and Miller, 1976, p. 37-41, pl. 1, figs. 1-8; text-figs. $1 \mathrm{~A}-\mathrm{C}$; text-figs. $2 \mathrm{~A}-\mathrm{H}$.

Specimen.-NSM-PP-9903 (Figures 3B, C).

Locality. - Taniyamadani, Shimoyama area.

Description.-Specimen consists of a partial pinna 8 $\mathrm{cm}$ long and $1.7 \mathrm{~cm}$ wide. Rachis of the pinna is about $2.5 \mathrm{~mm}$ and its upper surface is covered with the lamina. The lamina margin is entire. Segments of the lamina are rhomboidal, slightly revolute and as long as broad (ca. $10 \mathrm{~mm}$ ). They arise at an angle of about $60^{\circ}$ and imbricate slightly. The segments have an obtuse apex, notcontracted acroscopic angle and decurrent basiscopic angle. Veins are hardly seen in the parts where charred fragments of the very thick lamina remain (arrowheads in Figure 3B). About seven veins enter each segment. They fork less than twice and run almost parallel before ending in the margin of the segment. A concentration of the veins of $12-15$ per $\mathrm{cm}$ occurs in the middle part of a segment.

Comparison.-This specimen is identified as $C$. usnadzei, originally described from the Callovian of Georgia, which has very thick lamina dissected into rhomboidal segments with decurrent basiscopic base (Doludenko and Svanidze, 1969). The number of veins entering each segment in our specimen agrees with the emended diagnosis of C. usnadzei by Barnard and Miller (1976).

C. usnadzei is very similar to C. cycadea from the Lower Jurassic of Germany (Schenk, 1887; Harris, 1964). According to Barnard and Miller (1976), C. us- nadzei differs from C. cycadea in that the former has hypodermis in the laminae. This means the lamina of C. usnadzei is thicker than that of C. cycadea and this feature makes the venation hardly visible in compressed C. usnadzei specimens (Barnard and Millar, 1976). Contrary to Barnard and Miller's (1976) claim, interspecific variations in laminar and cuticular thicknesses are reported in C. cycadea, which could be attributed to conditions of insolation of the leaves (Barbacka and van Koijnenburg-van Cittert, 1998). Barbacka and van Koijnenburg-van Cittert (1998) also made note of the possibility that a criterion based on laminar and cuticular thicknesses could form artificially defined species. However, the exact taxonomic relationships between C. cycadea and C. usnadzei remain to be clarified at present. Therefore, we provisionally refer the specimen under study to C. usnadzei based on its thick lamina and hardly visible venation.

C. kachchhensis from the Middle to Upper Jurassic of Kachchh, India (Bose and Banerji, 1984) differs from the specimen because laminar segments of C. kachchhensis are broader than long. The specimen is similar to C. serrani, originally described from the Upper Triassic of Vietnam, in the shape of the laminar segments, but $C$. serrani differs in having more crowded veins entering the segments (Zeiller, 1903; Harris, 1961b).

\section{Class Cycadeoidopsida \\ Order Cycadeoidales Family uncertain \\ Genus Anomozamites Schimper, 1870 Anomozamites sp.}

Specimen.-NSM-PP-9917 (Figures 3D, E).

Locality.-Taniyamadani, Shimoyama area.

Description.-Specimen consists of a leaf fragment 5 $\mathrm{cm}$ long and $3 \mathrm{~cm}$ wide. The leaf is lanceolate. Rachis is $3 \mathrm{~mm}$ wide. Lamina is divided suboppositely into rectangular segments 4-12 $\mathrm{mm}$ long and 5-7 $\mathrm{mm}$ wide. The segments are entire, parallel-sided and attach to the upper side of the rachis at almost right angles. Narrow slits between the segments make segments imbricate. Veins are parallel, simple, seldom forked and concentrated with up to 40 veins $/ \mathrm{cm}$.

Comparison.-The specimen closely resembles $A$. minor from the Upper Triassic of Scoresby Sound, Greenland (Harris, 1926), A. sp. cf. minor from the Upper Triassic of Anhui, China (Sze, 1933) and $A$. sp. cf. minor from the Upper Triassic of Khorat, Thailand (Konno and Asama, 1973), in the narrow slits between the segments and crowded veins of the segments. However, the slits between the segments are slightly broader in A. minor than in the specimen. Additional specimens 
should be collected for further specific consideration.

Genus Otozamites Braun, 1843

Otozamites crassipinnatus T. Yamada and Uemura, sp. nov.

Holotype.-NSM-PP-9914 (Figures 3F, G).

Paratype.-NSM-PP-9916 (Figure 3H), NSM-PP9920 (Figure 3I). NSM-PP-9915 (Figure 3J).

Type locality.-Horadani, Kaizara area (NSM-PP9914, 9920)

Other localities.-Taniyamadani, Shimoyama area (NSM-PP-9915, 9916).

Etymology.-Compound of Latin adjective "crassus" meaning thick and Latin adjective "pinnatus" meaning pinnae.

Diagnosis.-Rachis completely covered by pinnae. Pinnae alternate, thick, convex adaxially, arising at $60^{\circ}$. Pinna margin reflexed. Acroscopic angle of pinna overlapping diagonal basiscopic angle of pinna. Pinna apex obtuse to round. Veins radiating from pinna attachment, forked, at maximum concentration there are ca. 40 per $\mathrm{cm}$.

Description.-Specimens on hand are a fragment of leaf $15.5 \mathrm{~cm}$ long and $3 \mathrm{~cm}$ wide (Figures $3 \mathrm{~F}, \mathrm{G}$ ) and detached pinnae (Figures $3 \mathrm{H}-\mathrm{J}$ ). The pinnatified leaf is parallel-sided. Petiole $2 \mathrm{~mm}$ in width is completely covered by the pinnae. Pinnae with reflexed margin 2$9 \mathrm{~cm}$ long, $1.4-3.5 \mathrm{~cm}$ wide, thick, convex and round to obovate-rhomboid. Pinnae attach alternately to the upper side of the petiole at $60^{\circ}$ by the middle of their basal margin. The basiscopic base of the pinnae is round or not contracted and the acroscopic base is rounded. The acroscopic base of the pinnae completely covers the basiscopic base of the diagonal pinna. The apex of the pinnae is obtuse to rounded. Veins are fine, radiating from the point of the pinna attachment and forking several times before ending at the margin. Their concentration is ca. 40 per $\mathrm{cm}$ at maximum.

Comparison.-Five species are reported so far which have round to obovate pinnae with reflexed margin similar to those of $O$. crassipinnatus, i.e., O. tenuatus, $O$. tenellus, $O$. boolensis, $O$. marginatus and $O$. beani. Of these $O$. crassipinnatus is most similar to O. tenuatus from the Aalenian of Yorkshire, but the size of the pinnae and the number of veins are much smaller in $O$. tenuatus (Leckenby, 1864; Harris, 1969). O. tenellus from the Lower Jurassic of Hunan, China is different in having a much narrower and smaller leaf with imbricated pinnae (Zhou, 1983). O. boolensis, from the Jurassic of Australia and Antarctica, sometimes has round to obovate pinnae, but it differs in the much smaller size of the pinnae and more sparse veins (Douglas, 1963;
Cantrill and Hunter, 2005). O. marginatus, initially described from the Bathonian of France, is distinguished from $O$. crassipinnatus in its imbricated pinnae, which is a diagnostic feature of that species (Saporta, 1875; Harris, 1969). Adding to this, the pinnae of $O$. crassipinnatus attach to the rachis at smaller angles than those of $O$. marginatus. O. beani described from the Bajocian of Yorkshire, UK is different in having more sparsely set pinnae (Harris, 1969).

\section{Otozamites sewardii Oishi, 1940}

Otozamites sewardii Oishi, 1940, p. 334, pl. 31, fig. 1.

Specimen.-NSM-PP-9901 (Figures 4C, D).

Locality.-Horadani, Kaizara area.

Description.-Specimen is a fragment of a leaf 10 $\mathrm{cm}$ long and wide. Petiole is $3 \mathrm{~mm}$ wide. Pinnae are elongate, $6 \mathrm{~cm}$ long, $0.6-0.8 \mathrm{~cm}$ wide, and attach to the upper side of the petiole by the slightly depressed midpoint of the pinnae base. Angle between rachis and pinnae is ca. $60^{\circ}$. Pinnae are contiguous at their base because auricle is weakly developed. Apex of pinnae is acuminate. About six veins arise at pinna base and each of them forks several times and ends at the pinna margin. The maximum concentration of veins is about 50 per $\mathrm{cm}$.

Comparison.-This specimen is identified as $O$. sewardii, the only species described previously from the Kaizara Formation, based on the feebly developed auricle, seldom overlapping pinnae, and elongate pinnae with acuminate apex (Oishi, 1940). O. sewardii is similar to $O$. pulcher from the Middle Jurassic of Elburz, Iran in pinnae shape (Barnard and Miller, 1976), but $O$. sewardii has more crowded veins in the pinnae than $O$. pulcher.

\section{Otozamites sp.}

Specimen.-NSM-PP-9913 (Figures 4A, B).

Locality.-Horadani, Kaizara area.

Description.-Specimen is a small fragment of leaf 2.2 $\mathrm{cm}$ long and $1.5 \mathrm{~cm}$ wide. Petiole is about $0.5 \mathrm{~mm}$ wide. Pinnae arise alternately at about $70^{\circ}$ and the acroscopic angle of the pinnae is contiguous to the basiscopic one in the diagonal position. Pinnae are $0.8 \mathrm{~cm}$ long, 0.5 $\mathrm{cm}$ wide and ovate. The apex of the pinnae is obtuse to rounded. The pinna base is depressed and the auricle is weakly developed. Six to seven veins arising from the base of the pinnae fork several times. Vein concentration is 35 per $\mathrm{cm}$. Usually one vein enters into the acroscopic auricle.

Comparison.-O. mimetes is characterized by contiguous pinnae arising at about $70^{\circ}$, feebly developed 

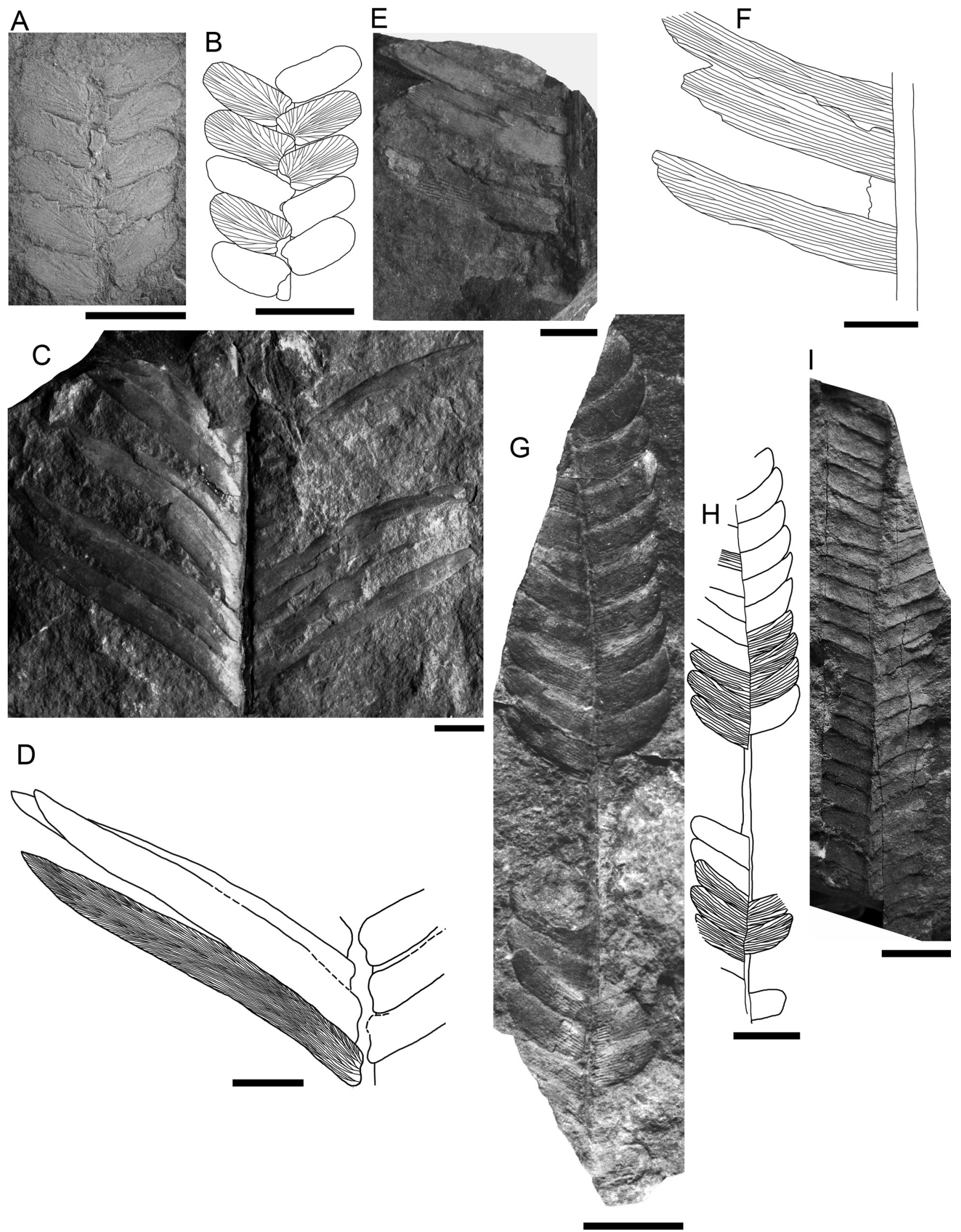

Figure 4. A. Otozamites sp., NSM-PP-9913. B. Line drawing of A. C. O. sewardii Oishi, NSM-PP-9901. D. Line drawing of C. E. Pterophyllum sp., NSM-PP-9919. F. Line drawing of E. G-I. Ptilophyllum caucasicum Doludenko et Svanidze. G. NSM-PP-9906. H. Line drawing of G. I. NSM-PP-9909. Scale bars $=1 \mathrm{~cm}$. 
acroscopic auricle, veins with a concentration of 30 per $\mathrm{cm}$ and round-obtuse to round-truncate apex of pinnae (Harris, 1949). These diagnostic features are concordant with the specimen described, thus it could be compared to $O$. mimetes. However, these external characters are also shared with $O$. walkamotaensis from the Upper Jurassic of Kachchh, India (Bose and Zeba-Bano, 1981). These two species can be distinguished from one another by their epidermal features; $O$. mimetes shows irregular arrangement of stomata (Harris, 1949; Barbacka et al., 2006), while $O$. walkamotaensis has distinct stomatiferous bands (Bose and Zeba-Bano, 1981). Unfortunately, this epidermal feature is not preserved in our specimen, and therefore we could not assign it to a species.

O. kachchhensis from the Middle to Upper Jurassic of Kachchh, India is closely similar to our leaf specimen in attachment and shape of pinnae, but differs from it in the smaller number of veins entering into the auricle (Bose and Banerji, 1984). It is also similar to O. contiguus from the Middle to Upper Jurassic of Kachchh, India, but is distinguished from $O$. contiguus because the latter has pinnae with acuminate apices (Feistmantel, 1876). $O$. kilpperiana from the Middle Jurassic of Elburz, Iran is similar to our specimen in pinnae shape, but in this species veins entering pinnae are less crowded than in our specimen (Barnard and Miller, 1976). O. margaritaceus also has small pinnae with vein concentration of 30 50 per cm (Zhou, 1983), but it is distinguished from our specimen in asymmetrical pinnae shape.

\section{Genus Pterophyllum Brongniart, 1828 Pterophyllum sp.}

Specimen.-NSM-PP-9919 (Figures 4E, F).

Locality.-Horadani, Kaizara area.

Description.-A leaf fragment $4 \mathrm{~cm}$ long, $3.8 \mathrm{~cm}$ wide, with pinnae of one side not preserved. Rachis is $2.5 \mathrm{~mm}$ wide and marked with three ribs on the side exposed (the opposite side is unknown). Lamina is thick. Pinnae are $3.6 \mathrm{~cm}$ long, $0.5-0.6 \mathrm{~cm}$ wide, closely set, and attach to the lateral side of the rachis at $70^{\circ}$. The base of the pinnae is neither contracted nor expanded. The acroscopic margin of the pinnae is nearly straight while the basiscopic margin gradually curves toward the apex from the distal third of the pinnae, so that the apex is asymmetrically rounded. Each pinna is entered by 9 12 veins, which fork several times before ending at the margin. The maximum concentration of veins is ca. 20 per $\mathrm{cm}$.

Comparison.-The specimen is similar to P. cheondaeriense from the Upper Triassic Amisan Formation, Cheondaeri, Korea in the closely set pinnae and in the number of ribs on the rachis and number of veins entering each pinnae (Kimura and Kim, 1989), but is distinguished from it by the veins forking at all levels and the pinnae with asymmetric rounded apex. This specimen could be assigned to a new species, but further observations on additional specimens would be required.

Genus Ptilophyllum Morris, 1840

Ptilophyllum caucasicum Doludenko et Svanidze, 1964
Ptilophyllum caucasicum Doludenko et Svanidze, 1964, p. 113-118, pl. 1, figs. 1-13; pl. 2, figs. 1-10; Doludenko et Svanidze, 1969, p. $65-67$, pl. 70, figs. 1-10; pl. 71, figs. 1-9.

Specimens.-NSM-PP-9906 (Figures 4G, H), NSMPP-9904 (Figure 5A), NSM-PP-9908 (Figure 5B), NSMPP-9907 (Figure 5C), NSM-PP-9909 (Figure 4I).

Locality.-Horadani, Kaizara area (NSM-PP-99049909, 9923)

Description.-The apicalmost and basalmost parts of the leaf are not preserved. Leaf was probably more than $10 \mathrm{~cm}$ long. Leaf slightly tapers towards both its ends, is less than $1.4 \mathrm{~cm}$ wide at the apex, $1.7-2 \mathrm{~cm}$ wide in the middle, and $1.2 \mathrm{~cm}$ wide near the base. Rachis of pinnae is ca. $1 \mathrm{~mm}$ wide. Pinnae attach suboppositely to the upper side of the rachis at about $60^{\circ}$. Size of the pinnae varies gradually along the proximal-distal axis of the leaf: they are $4 \mathrm{~mm}$ wide and $8 \mathrm{~mm}$ long near the distal end, $6 \mathrm{~mm}$ wide and $10 \mathrm{~mm}$ long at the middle part, and $3 \mathrm{~mm}$ wide and $6 \mathrm{~mm}$ long at the basal part. The pinnae on the same side of the rachis are imbricate. Apex of the pinnae is obtuse. Acroscopic base of the pinnae is not contracted while basiscopic base is slightly decurrent. About seven veins arising from the pinnae base sometimes fork a few times and the concentration of veins becomes 20-30 per $\mathrm{cm}$ at the middle of the pinnae length. Veins on the basiscopic and acroscopic sides diverge slightly while the other veins run almost parallel.

Comparison.-Specimens collected are identified as P. caucasicum, originally described from the Callovian of Georgia, based on concentration of veins and imbricated pinnae (Doludenko and Svanidze, 1964, 1969). $P$. caucasicum shows variations in its pinnae shape, i.e., from short pinnae with rounded apex to long pinnae with pointed apex (Doludenko and Svanidze, 1964, 1969). The specimens in hand are comparable to the short-type pinnae of $P$. caucasicum.

The specimens resemble $P$. shinadaniense from the Lower Jurassic Kuruma Group of Toyama Pref., Japan in their imbricate narrow pinnae (Kimura and Tsuji, 1982). However, the specimens are distinguished from $P$. shinadaniense because $P$. shinadaniense invariably has more elongate pinnae. They are also similar to $P$. 
hsingshanensis from the Middle Jurassic Xietan Formation of Hubei, China (Sze, 1949; Wu et al., 1980), but that species differs from our specimens in its narrower pinnae. P. guliqiaoense from the Early Cretaceous of Zhejiang, China also has convex and wide pinnae, but is distinguished from our specimens in having frequently forked veins (Cao, 1999). P. cutchense and P. sahnii from the Middle to Upper Jurassic of Kachchh, India have similar venation and leaf shape (Gupta and Sharma, 1968; Bose and Kasat, 1972), while our specimen has broader pinnae (i.e., $>3 \mathrm{~mm}$ ) than those species.

Two Japanese Ctenozamites species identified based on their external morphologies are similar to our specimens: Ctenozamites sp. from the Lower Cretaceous Oguchi Formation of Ishikawa Pref. (Kimura and Sekido, 1976b) and C. fukutomii from the Upper Jurassic to Lower Cretaceous Kiyosue Formation (sensu Yamada and Ohno, 2005) of Yamaguchi Prefecture (Kimura and Ohana, 1987b). They have distinctly isolated pinnae, while laminar segments of other Ctenozamites species are never isolated completely from adjacent segments, even in a species with highly dissected lamina (e.g., Schenk, 1887; Harris, 1961b, 1964, 1969). C. sp. is similar to our specimens in their pinnae shape, but our specimens can be distinguished from it in pinnae set more closely and less crowded veins. C. fukutomii is also similar to our specimens in pinnae shape, but it differs in that its pinnae are not imbricate. Thus, they are actually species of the genus Ptilophyllum.

\section{Ptilophyllum sp. A}

\section{Specimens.-NSM-PP-9905 (Figure 5D), NSM-PP-} 9923 (Figure 5E, F).

Locality.-Horadani, Kaizara area.

Description.-The basalmost part of the leaf is not preserved. Leaf is probably more than $8 \mathrm{~cm}$ long and slightly tapers towards apex: less than $0.8 \mathrm{~cm}$ wide at the apex, $1.5 \mathrm{~cm}$ wide in the middle. Rachis with 0.5 $\mathrm{mm}$ width is covered by pinnae with slight exposure in its central part. Pinnae are ca. $2 \mathrm{~mm}$ wide and 6 to 8 $\mathrm{mm}$ long and closely attach suboppositely to the upper side of the rachis at 50 to 60 degrees. The pinna apex is obtusely rounded. The acroscopic base of the pinnae is slightly contracted while the basiscopic base is decurrent. Eight or nine veins arise from the pinnae base and fork once or twice. The concentration of veins is 40 to 50 per $\mathrm{cm}$. The veins run almost parallel.

Comparison.-The specimens obtained are indistinguishable in external morphology both from $P$. cutchense, which was reported from the Middle to Upper Jurassic of Kachchh, India by Bose and Kasat (1972), and P. choshiense from the Choshi Group of Japan (Kimura et al., 1991). However, the diagnostic features of both species are on their epidermis, and thus we could not assign our specimens to those species. This specimen closely resembles Ptilophyllum ex gr. P. pecten from the Yuasa and Arida formations of Japan (Kimura and Kansha, 1978).

\section{Ptilophyllum sp. B}

Specimen.-NSM-PP-9918 (Figures 5G, H).

Locality.-Taniyamadani, Shimoyama area.

Description.-Specimen is a leaf fragment without basal and apical part $3 \mathrm{~cm}$ long and $5 \mathrm{~cm}$ wide. Apex of pinnae is missing. Rachis of pinnae is completely covered by pinnae. Pinnae are ca. $0.4 \mathrm{~cm}$ wide and more than $2.5 \mathrm{~cm}$ long and attach suboppositely to the upper side of the rachis at $60^{\circ}$. Pinnae on the same side are imbricate. Acroscopic base of the pinnae is slightly contracted while basiscopic base is decurrent. Eight or nine veins arise from the pinnae base and fork once or twice. Concentration of veins is 20 to 30 per $\mathrm{cm}$. Veins run almost parallel.

Comparison.-The specimen resembles the elongatepinnae type of $P$. caucasicum (Doludenko and Svanidze, 1969) in pinnae shape and the number of veins entering each pinnae. Taking into account that some specimens of $P$. caucasicum of the short-pinnae type were collected at the same locality, this specimen might be the longpinnae type of $P$. caucasicum. P. elongatum Kimura and Ohana from the Lower Cretaceous Choshi Group of Japan also has elongate pinnae (Kimura and Ohana, 1984; Kimura et al., 1991), but its pinnae width is about half that of our specimen.

\section{Class Cycadopsida Order Cycadales Family uncertain \\ Genus Pseudoctenis Seward, 1911 Pseudoctenis? sp.}

Specimen.-NSM-PP-9902 (Figures 5I-K). Locality.-Taniyamadani, Shimoyama area.

Description.-Leaf fragment $11.5 \mathrm{~cm}$ long and $11 \mathrm{~cm}$ wide, pinnae on one side of the rachis are not preserved. The rachis is marked with fine longitudinal striations, stout, and $1.1 \mathrm{~cm}$ wide. Pinnae are $11 \mathrm{~cm}$ long and vary in width along their length; they are $4 \mathrm{~mm}$ wide at the base, $5 \mathrm{~mm}$ wide at the middle and then taper to a pointed apex. Pinnae attach to the upper-lateral side of the rachis at $70^{\circ}$. Base of the pinnae slightly contracted on both acroscopic and basiscopic sides and a crescentic mound is developed at the base. Intervals between the pinnae are ca. $4 \mathrm{~mm}$. Veins are seldom forked and at 


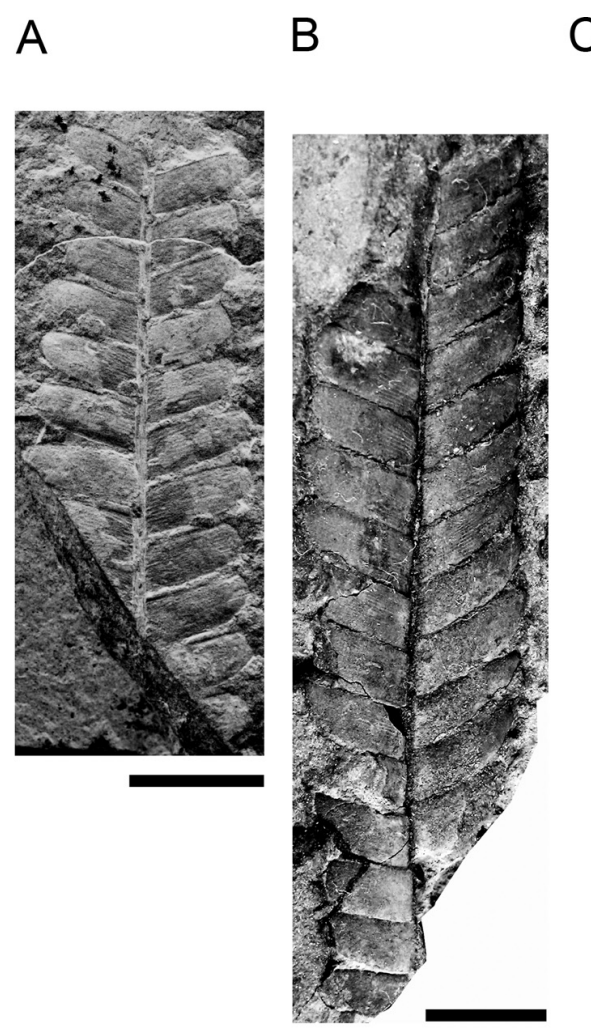

C

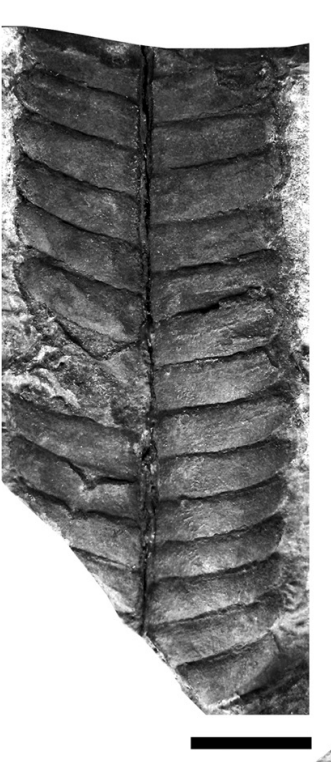

D

E
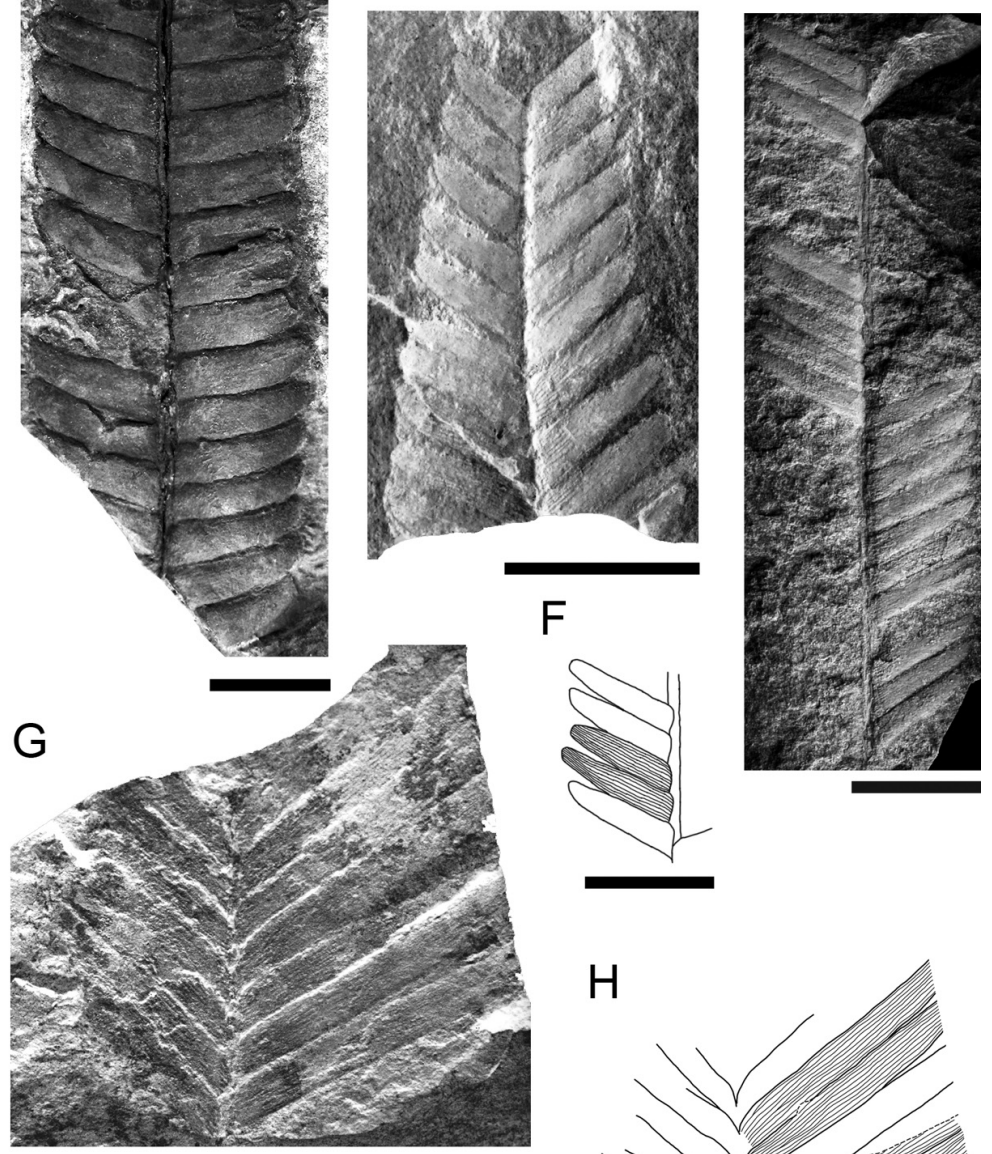

F

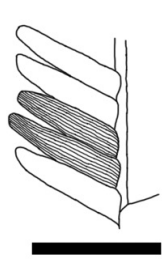

E 
concentrations of up to 35-40 per $\mathrm{cm}$.

Comparison.-Pinnae of genus Zamites (Bennetitales) also have an equally contracted base and attach to the upper side of the rachis. Unfortunately, the epidermal features essential for distinguishing Zamites from Pseudctenis are not preserved in our specimen. Therefore, the possibility could not be ruled out that the specimen belongs to Zamites.

The specimen is similar to Pseudctenis sp. reported from the Callovian of Elburz, Iran by Barnard and Miller (1976) in the narrow pinnae attaching to the upper-lateral side of a stout rachis by a slightly contracted base. However, the veins in the pinnae are more crowded in this specimen than in Barnard and Miller's (1976) specimen. Our specimen is also similar to P. fragilis from the Middle Jurassic of Kachchh, India in the shape of the pinnae base, but that species has less crowded veins on the pinnae (Bose and Banerji, 1984).

The specimen is also similar to Pterophyllum pachyrachis from Mochiana, although this species is included in a different genus (Oishi, 1940; Kimura and Ohana, 1987b). Our specimen resembles it in narrow pinnae attached to the upper-lateral side of a broad rachis, but differs from $P$. pachyrachis in the more elongate pinnae and acuminate pinna apex.

\section{Class Coniferopsida Order Coniferales Family uncertain Form-genus Elatocladus Halle, 1913 Elatocladus sp.}

Specimen.-NSM-PP-9911 (Figures 6A, B).

Locality.-Taniyamadani, Shimoyama area.

Description.-A fragment of shoot without base and apex $6 \mathrm{~cm}$ long and $2.5 \mathrm{~cm}$ wide. Stem is $1.5 \mathrm{~mm}$ wide and bears helically arranged scale leaves with faint midrib. Angle between adjacent leaves is usually 60 to 80 degrees, but the phyllotaxy is uncertain, because some of the leaves are not observed in the compressed specimen. The leaves are compressed along the adaxial-abaxial axis, are linear in shape and have an acuminate apex. They attach to the stem almost at right angles via their decurrent base, while the angles between the leaf and stem become smaller near the shoot apex. The leaves are $1-1.2 \mathrm{~cm}$ long, and $1-1.5 \mathrm{~mm}$ wide in the part free from the stem.

Comparison.-The specimen is closely similar to $E$. zamioides from the Middle Jurassic of Yorkshire, UK in angle between adjacent scale leaves, and leaves with short petiole and acuminate apex (Harris, 1979). However, E. zamioides differs from the specimen in having opposite and more elongate leaves.
Form-genus Pagiophyllum Heer, 1881 Pagiophyllum? sp.

Specimen.-NSM-PP-9910 (Figures 6C, D).

Locality.-Taniyamadani, Shimoyama area.

Description.-A shoot fragment $6.2 \mathrm{~cm}$ long and 1.5 $\mathrm{cm}$ wide. The apex and base of the shoot are not preserved. The stem is $1.8 \mathrm{~mm}$ wide. Leaves are arranged helically and sparsely, but phyllotaxy is uncertain because the specimen is obliquely compressed. The free parts of the leaves are 6-8 $\mathrm{mm}$ long and 3-3.5 $\mathrm{mm}$ wide, and the angle between the stem and free parts of the leaf is ca. $90^{\circ}$. The base of the leaves is slightly contracted and the decurrent part is $3 \mathrm{~mm}$ wide. The apex of the leaves is obtuse. The adaxial surface of the leaves is convex, while the abaxial one is not observed in the compressed specimen.

Comparison.-The specimen is too compressed to examine the thickness of the leaves, which is one of the generic diagnostic features of Pagiophyllum. However, as to the diagnostic characters which could be observed in the specimen, it is similar to Pagiophyllum: the leaves are longer and slightly broader than their decurrent base. Among Pagiophyllum species, the specimen is similar to $P$. kurrii from the Lower Jurassic of Germany and the Middle Jurassic of Yorkshire, UK in their sparsely set leaves and slightly contracted leaf base (Salfeld, 1907; Harris, 1979).

\section{Discussion}

\section{Characteristics of the Kaizara Flora}

Here, the name Kaizara flora is proposed for the Middle Jurassic (Bathonian to Callovian) plant fossils from the Kaizara Formation. In addition to already described Otozamites sewardii (Oishi, 1940), twelve species are newly reported; they belong to Equisetales, uncertain order of pteridosperms, Cycadeoideales, Cycadales, and Coniferales (Table 1). Most of these gymnospermous taxa have very thick lamina. The flora is most characterized by abundant microphyllous cycadeoidealean taxa (sensu Ziegler et al., 1996; Rees et al., 2000), such as Otozamites and Ptilophyllum species. Scantiness of pteridophytes and absence of ginkgophytes and Nilssonia are other prominent features of the flora. Despite extensive searches over twenty years, such taxa were not discovered from the area, except for small fragments of Gleichenites-like pinnule (data not shown in this study). The offshore sedimentary environments of the Kaizara Formation are a possible cause of the peculiar assemblage, but this can not fully explain the taphonomic bias, because these underrepresented taxa are often recovered from offshore sediments from other formations such as 

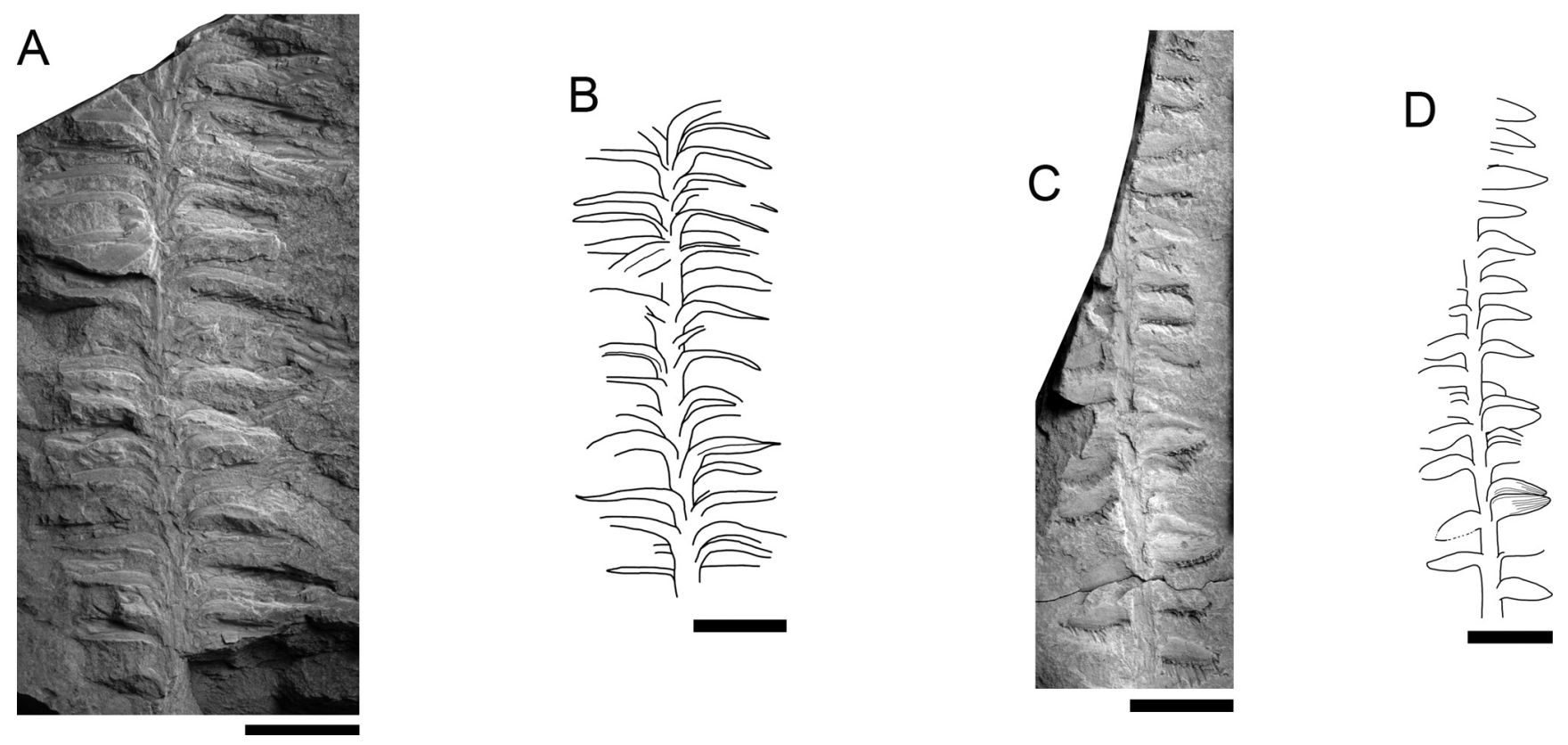

Figure 6. A. Elatocladus sp., NSM-PP-9911. B. Line drawing of A. C. Pagiophyllum? sp., NSM-PP-9910. D. Line drawing of C. Scale bars $=1 \mathrm{~cm}$.

the Toyora Group (Yamada and Ohno, 2005), the Yezo Group (Oishi, 1940), the Choshi Group (Kimura and Okubo, 1985), and the Kamihambara Formation of the Tetori Group (T. Yamada, unpublished data).

Multivariate statistical analysis was conducted to assess the distributional link among 57 foliar genera reported from the Jurassic strata of the Northern Hemisphere and the results were further correlated to the paleoclimate (Ziegler et al., 1993, 1996; Rees et al., 2000). As a result, it was suggested that the microphyllous cycadophytes and conifers favored a climate under which dry conditions prevailed at least during a part of a year, while macrophyllous conifers and ginkgophytes favored cool temperate conditions. Other foliar genera, such as those of some pteridophytes, conifers and macrophyllous cycadophytes, show the maximum abundance of their diversity in warm temperate climates (Rees et al., 2000). The Kaizara flora includes abundant species of microphyllous cycadophytic and coniferous genera (Otozamites, Ptilophyllum and Pagiophyllum), as well as species of Equisetites, Anomozamites, Pterophyllum, and Elatocladus which are indicators of a warm temperate climate. This would suggest that the Kaizara flora grew under a seasonally wet climate. The leaf physiognomy observed in species of the Kaizara flora, i.e., leaves with very thick lamina, would support the existence of dry period(s) in the climate.

Only two coeval late Bathonian to Callovian floras were reported whose ages are unequivocally controlled,
Table 1. List of the Kaizara flora. Figures show the number of collected specimens.

\begin{tabular}{|c|c|c|}
\hline Species & Kaizara & Shimoyama \\
\hline \multicolumn{3}{|c|}{ Pteridophyte } \\
\hline (Equisetales) & & \\
\hline Equisetites sp. & 1 & \\
\hline \multicolumn{2}{|c|}{ Gymnosperms } & (Pteridosperms) \\
\hline Ctenozamites usnadzei & & 1 \\
\hline \multicolumn{3}{|c|}{ Doludenko \& Svanidze } \\
\hline \multicolumn{3}{|l|}{ (Cycadeoideales) } \\
\hline Anomozamites sp. & & 1 \\
\hline Otozamites crassipinnatus & 2 & 2 \\
\hline \multicolumn{3}{|c|}{ T. Yamada \& Uemura } \\
\hline O. sewardi Oishi & & 1 \\
\hline$O$. sp. & & 1 \\
\hline Pterophyllum sp. & 1 & \\
\hline Ptilophyllum caucasicum & 9 & \\
\hline \multicolumn{3}{|c|}{ Doludenko \& Svanidze } \\
\hline Ptilophyllum sp. A & 2 & \\
\hline $\begin{array}{l}\text { Ptilophyllum sp. B } \\
\text { (Cycadales) }\end{array}$ & 1 & \\
\hline $\begin{array}{l}\text { Pseudoctenis? sp. } \\
\text { (Coniferales) }\end{array}$ & & 1 \\
\hline Elatocladus sp. & & 1 \\
\hline Pagiophyllum? sp. & & 1 \\
\hline
\end{tabular}

one from the Caucasian Province, Georgia (Doludenko and Svanidze, 1969) and the other from Elburz, Iran (Barnard and Miller, 1976). These two floras are similar to the Kaizara flora in the abundance of Otozamites and 
Ptilophyllum species. However, the Kaizara flora differs from these in the occurrence of the genera Equisetites and Elatocladus, which would favor the interpretation of a warm temperate climate (Rees et al., 2000).

\section{Stratigraphic significance}

This study has clearly shown that there is no common species between the Kaizara and other Tetori-type floras proposed in the Tetori Group. Taking the late Bathonian to Callovian age of the Kaizara flora into account, this result implies that the Tetori-type flora appeared later than the Callovian in the land of the Tetori Group. Based on a recently compiled stratigraphic scheme (Fujita, 2003; Figure 2), the oldest records of the Tetori-type flora in the Tetori Group are those from the Tithonian Ashidani (formerly assigned to the Ochiai Formation: Kimura, 1958) and Ushimaru formations (Kimura, 1958; Maeda, 1961a, b).

The exact age of the Jurassic and Lower Cretaceous strata is difficult to establish paleontologically in East Asia except for Far East Russia and Japan since they consist mostly of nonmarine deposits (e.g., Arkell, 1956; Chen et al., 1982). Therefore, phytostratigraphy could be a powerful tool by which to correlate the Jurassic and Lower Cretaceous strata if it is worked out in Japan and Far East Russia where marine and terrestrial facies are often intercalated (Sato et al., 1963; Sato, 1992; Kirillova and Kiriyanova, 2003). Oishi (1933a, b, 1940) stressed the significance of Onychiopsis, a pteridophyte genus unclassified as to family, in Japanese Jurassic to Cretaceous biostratigraphy when he proposed an "Onychiopsis Series" as a local chronozone ranging from the Oxfordian to early Cretaceous. In his study, the first appearance of $O$. elongata (Geyler) Yokoyama, a representative of the Tetori-type flora (e.g., Kimura, 1988), was estimated as the Oxfordian in the Tetori Group. Later, his claim was dismissed as so-called middle Jurassic assemblages including Onychiopsis were proposed, such as the "Kuzuryu" and "Utano" floras. However, recent progress in stratigraphy of the Mesozoic System indicates that this counterevidence for the lower limit of the "Onychiopsis Series" is no longer sustainable (Yamada et al., 1989; Fujita, 2002; Sato et al., 2003; Sato and Yamada, 2005; Yamada and Ohno, 2005). Results of this study also suggested the post-Oxfordian appearance of Onychiopsis in the Tetori Group.

As far as the Mesozoic strata of Japan are concerned, the appearance of Onychiopsis after the Oxfordian seems to be sound because O. yokoyamai, another Onychiopsis species reported from Japan (Kimura and Aiba, 1986), is found in post-Oxfordian deposits (Kimura and Ohana, 1989; Kimura et al., 1990). In Far East Russia, the oldest reliable record of the genus is O. elongata from the Berriasian of Amur and Lena provinces (Kirillova and Kiriyanova, 2003). Volynets (1997) compared the Onychiopsis-bearing Alexeevsky floristic assemblage to the Utano flora and considered its age as Aalenian to Bathonian, following the previous age estimate on the Utano flora (Kimura et al., 1986; Kimura and Ohana, 1987a). However, the age of the Utano flora is now revised to Late Jurassic to Early Cretaceous (Yamada and Ohno, 2005). Therefore, the appearance of Onychiopsis after the Oxfordian is also applicable to Far East Russia, implying that its appearance after the Oxfordian could be a shared event in Eastern Asia.

\section{Acknowledgments}

I thank K. Hachiya, T. Hayashi and Y. Mizuno for providing materials used in this study. M. Kato and $\mathrm{T}$. Sato kindly revised this manuscript. This study is partly supported by a research project of the National Museum of Nature and Science, entitled "Historical development and origin of biodiversity under the global environmental dynamics".

\section{References}

Arkell, W. J., 1956: Jurassic Geology of the World, 806 p. Oliver and Boyd, Edinburgh.

Barbacka, M., Pálfy, J. and Smith, P. L., 2006: Hettangian (Early Jurassic) plant fossils from Puale Bay (Peninsular terrane, Alaska). Review of Palaeobotany and Palynology, vol. 142, p. 33 $-46$.

Barbacka, M. and van Konijnenburg-van Cittert, J. H. A. 1998: Sun and shade leaves in two Jurassic species of pteridosperms. Review of Palaeobotany and Palynology, vol. 103, p. 209-221.

Barnard, P. D. W. and Miller, J. C., 1976: Flora of the Shemshak Formation (Elburz, Iran), Part 3: Middle Jurassic (Dogger) plants from Katumbargah, Vasek Gah and Imam Manak. Palaeontographica, Abt. B, vol. 155, p. 31-117.

Bose, M. N. and Banerji, J., 1984: The fossil floras of Kachchh. IMesozoic megafossils. Palaeobotanist, vol. 33, p. 1-189.

Bose, M. N. and Kasat, M. L., 1972: The genus Ptilophyllum in India. Palaeobotanist, vol. 19, p. 115-145.

Bose, M. N. and Zeba-Bano, 1981: On a new species of Otozamites from Kachchh, western India. Palaeobotanist, vol. 27, p. 227231.

Braun, C. F. W., 1843: Beiträge zur Urgeschichte der Pflanzen. In Münster, G. ed., Beiträge zur Petrefactenkunde. Heft 6, p. 1-33. Bayreuth.

Brongniart, A., 1828: Prodrome d'une histoire des végétaux fossiles. Dictionnaire des Sciences Naturelles, vol. 57, p. 61-212.

Cantrill, D. J. and Hunter, M. A., 2005: Macrofossil floras of the Latady Basin, Antarctic Peninsula. New Zealand Journal of Geology and Geophysics, vol. 48, p. 537-553.

Cao, Z., 1999: Early Cretaceous flora of Zhejiang. Palaeontologia Sinica, New Series A, no. 13.

Chen, P., Li, W., Chen, J., Ye, C., Wang, Z., Shen, Y. and Sun, D., 1982: Stratigraphical classification of Jurassic and Cretaceous in China. Scientia Sinica, Series B, vol. 25, p. 1227-1248.

Doludenko, M. P. and Svanidze, T. I., 1964: Some Jurassic Ptilophyl- 
lum fronds of Ukraine and Georgia and their correlation with Indian species of this genus. In, International Geological Congress 22nd Session. Report of Soviet Geologists. Problem 9, p. 111-122. Nauka, Moscow. (in Russian)

Doludenko, M. P. and Svanidze, T. I., 1969: The Late Jurassic flora of Georgia. Transactions of Geological Institute, Academy of Sciences of USSR, vol. 178, p. 1-118. (in Russian)

Douglas, J. G., 1963: New bennettitalean leaves from the Mesozoic of eastern Australia. Proceedings of the Royal Society of Victoria, vol. 77, p. 197-206.

Feistmantel, O., 1876: Fossil flora of Gondwana System. Jurassic (Oolitic) flora of Kach. Memoirs of Geological Survey of India, Palaeontologia Indica, Series 11, vol. 2, p. 1-80.

Fujita, M., 2002: A new contribution to the stratigraphy of the Tetori Group, adjacent to Lake Kuzuryu, Fukui Prefecture, Central Japan. Memoir of the Fukui Prefectural Dinosaur Museum, vol. 1, p. 41-53.

Fujita, M., 2003: Geological age and correlation of the vertebratebearing horizons in the Tetori Group. Memoir of the Fukui Prefectural Dinosaur Museum, vol. 2, p. 3-14.

Geyler, H. T., 1877: Über fossile Pflanzen aus der Juraformation Japans. Palaeontographica, vol. 24, p. 221-232, pls. 30-34.

Goto, M., 2007: An Early Cretaceous ammonoid from the Itoshiro Subgroup of the Tetori Group in the Uchinami River area of Ohno City, Fukui Prefecture, Central Japan. Memoir of the Fukui Prefectural Dinosaur Museum, vol. 6, p. 27-34. (in Japanese with English abstract).

Gupta, K. M. and Sharma, B. D., 1968: Investigations on the Jurassic flora of the Rajmahal Hills, India. 2-On a new species of Ptilophyllum, P. sahnii from Amarjola in Amarapara region. Journal of the Palaeontological Society of India, vol. 11, p. 19-66.

Halle, T. G., 1913: The Mesozoic flora of Graham Land. Wissenschaftliche Ergebnisse der Schwedischen Südpolar-Expedition, 1901-1903, vol. 3, p. 1-122.

Harris, T. M., 1926: The Rhaetic flora of Scoresby Sound, east Greenland. Meddelelser om Grønland, vol. 68, p. 44-148.

Harris, T. M., 1949: Notes on the Jurassic flora of Yorkshire, 40-42. 40. Otozamites anglica (Seward) comb. nov.; 41. The narrowleaved Otozamites species; 42. Ptilophyllum hirsutum Thomas and Bancroft and its differentiation from P. pecten (Phillips.). Annals and Magazine of Natural History, London, ser. 12, vol. 1, p. 275-299.

Harris, T. M., 1961a: The Yorkshire Jurassic flora I. ThallophytaPteridophyta. British Museum (Natural History), London.

Harris, T. M., 1961b: The form and structure of Ctenozamites cycadea (Berger) Schenk. Bulletin of the British Museum (Natural History) Geology, vol. 5, p. 159-173, pls. 31-32.

Harris, T. M., 1964: The Yorkshire Jurassic flora II. Caytoniales, Cycadales and Pteridosperms. British Museum (Natural History), London.

Harris, T. M., 1969: The Yorkshire Jurassic flora III. Bennettitales. British Museum (Natural History), London.

Harris, T. M., 1979: The Yorkshire Jurassic flora V. Coniferales. British Museum (Natural History), London.

Heer, O., 1881: Contributions à la flore fossile de Portugal. Lisbon.

Kimura, T., 1958: On the Tetori flora (Part 1). Mesozoic plants from the Kuzuryu Sub-Group, Tetori Group, Japan. Bulletin of the Senior High School attached to the Tokyo University of Education, vol. 2.2, p. 1-47.

Kimura, T., 1975: Middle-Late Early Cretaceous plants newly found from the upper course of the Kuzuryu River Area, Fukui Prefecture, Japan. Transactions and Proceedings of the Palaeontogical Society of Japan, New Series, no. 98, p. 55-93.

Kimura, T., 1987: Recent knowledge of Jurassic and Early Cretaceous floras in Japan and phytogeography of this time in East Asia. Bulletin of the Tokyo Gakugei University, Sect. 4, vol. 39, p. 87115.

Kimura, T., 1988: Jurassic macrofloras in Japan and palaeophytogeography in East Asia. Bulletin of the Tokyo Gakugei University, Section 4, vol. 40, p. 147-164.

Kimura, T. and Aiba, H., 1986: Onychiopsis yokoyamai (Yabe) comb. nov. from the Lower Cretaceous Plant-beds in the Outer Zone of Japan. Bulletin of the National Science Museum, Tokyo, Series C, vol. 12, p. 41-52.

Kimura, T. and Kansha, Y., 1978: Early Cretaceous plants from the Yuasa District and the Aridagawa Valley, Wakayama Prefecture, in the Outer Zone of Japan. Bulletin of the National Science Museum, Tokyo, Series C, vol. 4, p. 99-116, pls. 1-4.

Kimura, T. and Kim, B. K., 1989: New taxa in the Late Triassic Daedong flora, south Korea. Part 2. Transactions and Proceedings of the Palaeontogical Society of Japan, New Series, no. 155, p. 141158.

Kimura, T. and Ohana, T., 1984: Ptilophyllum elongatum sp. nov., from the Lower Barremian Kimigahama Formation, the Choshi Group, in the Outer Zone of Japan. Proceedings of the Japan Academy, Series B, vol. 60, p. 381-384.

Kimura, T. and Ohana, T., 1987a: Middle Jurassic and some Late Liassic plants from the Toyora Group, southwest Japan (I). Bulletin of the National Science Museum, Tokyo, Series C, vol. 13, p. 41-76.

Kimura, T. and Ohana, T., 1987b: Middle Jurassic and some Late Liassic plants from the Toyora Group, southwest Japan (II). Bulletin of the National Science Museum, Tokyo, Series C, vol. 13, p. 115148.

Kimura, T. and Ohana, T., 1989: Late Jurassic plants from the Oginohama Formation, Oshika Group in the Outer Zone of Northeast Japan (I). Bulletin of the National Science Museum, Tokyo, Series $C$, vol. 15, p. 1-24.

Kimura, T. Ohana, T. and Aiba, H., 1990: Late Jurassic plants from the Shishiori Group, in the Outer Zone of Northeast Japan (I). Bulletin of the National Science Museum, Tokyo, Series C, vol. 16, p. 127-153.

Kimura, T., Ohana, T., Kurihara, Y. and Komori, K., 1986: Middle Jurassic Utano flora and its significance for biostratigraphy and palaeophytogeography in East Asia (abstract). Proceedings of the Japan Academy, Series B, vol. 62, p. 341-344.

Kimura, T. and Okubo, A., 1985: Nilssonia dictyophylla sp. nov. from the Lower Cretaceous Choshi Group, in the Outer Zone of Japan. Proceedings of the Japan Academy, Series B, vol. 61, p. 430-432.

Kimura, T., Okubo, A. and Miyahashi, H., 1991: Cuticular study of Ptilophyllum leaves from the Lower Cretaceous Choshi Group, in the Outer Zone of Japan. Bulletin of the National Science Museum, Tokyo, Series C., vol. 17, p. 129-152.

Kimura, T. and Sekido, S., 1976a: Dictyozamites and some other cycadophytes from the early Lower Cretaceous Oguchi Formation, the Itoshiro Group, Central Honshu, Japan. Transactions and Proceedings of the Palaeontogical Society of Japan, New Series, no. 101, p. 291-312, pls. 30-32.

Kimura, T. and Sekido, S., 1976b: Mesozoic plants from the Akaiwa Formation (Upper Neocomian), the Itoshiro Group, Central Honshu, Japan. Transactions and Proceedings of the Palaeontogical Society of Japan, New Series, no. 103, p. 343-378, pls. 36-39.

Kimura, T., Sekido, S. and Yamazaki, Y., 1978: Plant fossil assemblage from the Oguchi and the Akaiwa Formations of the Itoshiro Subgroup, with special emphasis on the fossils from the Shiramine Village, Ishikawa Pref., central Japan. In, Ishikawa Prefectural Board of Education, ed., Research report on the silicified wood localities of the Tetori Group along the Tedori River, p. 119-271. Ishikawa Prefectural Board of Education, Japan (In Japanese). 
Kimura, T. and Tsuji, M., 1982: Early Jurassic plants in Japan. Part 4. Transactions and Proceedings of the Palaeontogical Society of Japan, New Series, no. 125, p. 259-276.

Kirillova, G. L. and Kiriyanova, V. V., 2003: J/K boundary in Southeastern Russia and possible analogue of the Tetori Group, Japan. Memoir of the Fukui Prefectural Dinosaur Museum, vol. 2, p. 75102.

Konno, E. and Asama, K., 1973: Contributions to the geology and palaeontology of Southeast Asia, 122. Mesozoic plats from Khorat, Thailand. Geology and Palaeontology of Southeast Asia, vol. 12, p. 149-171.

Kusuhashi, N., Matsumoto, A., Murakami, M., Tagami, T., Hirata, T., Iizuka, T., Handa, T. and Matsuoka, H., 2006: Zircon U-Pb ages from tuff beds of the upper Mesozoic Tetori Group in the Shokawa district, Gifu Prefecture, central Japan. Island Arc, vol. 15, p. 378-390.

Leckenby, G., 1864: On the sandstones and shales of the oolites of Scarborough, with descriptions of some new species of fossil plants. Quarterly Journal of the Geological Society, vol. 20, p. $74-82$.

Maeda, S., 1952: A stratigraphical study on the Tetori Series in the Upper Shiokawa District in Gifu Prefecture. Journal of the Geological Society of Japan, vol. 58, p. 145-153. (in Japanese)

Maeda, S., 1956: Stratigraphy and geological structure of the Tetori Group on the borderland of Fukui and Gifu Prefectures. Journal of the Geological Society of Japan, vol. 63, p. 225-237. (in Japanese)

Maeda, S., 1960: Stratigraphy of the Tetori Group in the southern part of the Kuzuryu River, Fukui Prefecture. Journal of the Geological Society of Japan, vol. 67, p. 23-31. (in Japanese)

Maeda, S., 1961a: On the geological history of the Mesozoic Tetori Group in Japan. Journal of College of Arts and Sciences, Chiba University. Natural Sciences Series, vol. 3, p. 369-426. (in Japanese)

Maeda, S., 1961b: The Tetori Group along the Asuwa River in Fukui Prefecture. Journal of Geography, vol. 70, p. 65-69.

Matsukawa, M., Ito, M., Nishida, N., Koarai, K., Lockley, M. G. and Nichols, D. J., 2006: The Cretaceous Tetori biota in Japan and its evolutionary significance for terrestrial ecosystems in Asia. Cretaceous Research, vol. 27, p. 199-225.

Morris, J., 1940: Typification of Ptilophyllum. In, Grant, C. W., Memoir to illustrate a geological map of Cutch. Transactions of the Geological Society, London, vol. 5, p. 289-329, pls. 20-26.

Nathorst, A. G., 1886: Om floran i Skånes kolförande Bildingar. I. Floran vid Bjuf. Sveriges Geologiska Undersökning Serie C, vol. 85 , p. $83-116$.

Oishi, S., 1933a: On the Tetori Series, with special references to its fossil zones. Part 1. Journal of the Geological Society, Tokyo, vol. 40, p. 617-644. (in Japanese)

Oishi, S., 1933b: On the Tetori Series, with special references to its fossil zones. Part 1. Journal of the Geological Society, Tokyo, vol. 40, p. 669-699. (in Japanese)

Oishi, S., 1940: The Mesozoic floras of Japan. Journal of the Faculty of Sciences, Hokkaido Imperial University, Section 4, vol. 5, p. 123-480.

Rees, P. McA., Ziegler, A. M. and Valdes, P. J., 2000: Jurassic phytogeography and climates: new data and model comparisons. In, Huber, B. T., Macleod, K. G. and Wing, S. L. eds., Warm climates in Earth history, p. 297-318. Cambridge University Press, Cambridge.

Salfeld, H., 1907: Fossile Land-Pflanzen der Rät- und Juraformation Südwestdeutschlands. Palaeontographica Stuttgart, vol. 53, p. 164-204.

Saporta, G., 1873-1875: Paléontologie française ou description des fossils de la France (2, Végétaux), Plantes jurassiques, vol. II, Cycadeés. 548 p. 74 pls., Paris.

Sato, T., 1962: Études biostratigraphiques des ammonites du Jurassique du Japon. Mémoires de la Société Géologique de France, vol. 94 , p. 1-122.

Sato, T., 1992: Southeast Asia and Japan. In Westermann, G. E. G. ed., The Jurassic of the Circum Pacific, p. 194-213. Cambridge University Press, Cambridge.

Sato, T., Hachiya, K. and Mizuno, Y., 2003: Latest Jurassic-Early Cretaceous ammonites from the Tetori Group in Shokawa, Gifu Prefecture. Bulletin of the Mizunami Fossil Museum, vol. 30, p. $151-167$.

Sato, T., Hayami, I., Tamura, M. and Maeda, S., 1963: The Jurassic. In Takai, F., Matsumoto, T. and Toriyama, R. eds., Geology of Japan, p. 79-98. University of Tokyo Press, Tokyo.

Sato, T. and Kanie, Y., 1963: Lilloetia sp. (Ammonite callovienne) de Mitarasi au Bassin de Tetori. Transactions and Proceedings of the Palaeontogical Society of Japan, New Series, no. 49, p. 8.

Sato, T. and Westermann, G. E. G., 1991: Japan and South-East Asia. Jurassic taxa ranges and correlation charts for the Circum-Pacific, 6. Newsletter on Stratigraphy, vol. 24, p. 81-108.

Sato, T. and Yamada, T., 2005: A Lower Tithonian (Upper Jurassic) ammonite Parapallasiceras newly discovered from the Itoshiro Subgroup (Tetori Group) in Izumi-mura, Fukui Prefecture. Proceedings of the Japan Academy Series B, vol. 81, p. 267-272.

Schenk, A., 1887: Fossile Pflanzen aus der Albourskette. Bibliotheca Botanica, Abhandlungen aus dem Gesammtgebiete der Botanik, vol. 6, p. 1-12.

Schimper, W. P., 1870: Traité de paléontologie végétale, vol. 2. J. B. Baillière et Fils, Paris.

Seward, A. C., 1911: The Jurassic flora of Sutherland. Transactions of the Royal Society of Edinburgh, vol. 47, p. 643-709.

Sternberg, C. von, 1833. Versuch einer geognostisch-botanischen Darstellung der Flora der Vorwelt, Hefte 5, 6. 80 p., 22 pls. Leipzig and Prague.

Sze, H. C., 1933: Beiträge zur mesozoischen Flora von China. Palaeontologia Sinica, Series A, vol. 4, p. 1-92.

Sze, H. C., 1949: Die mesozoische Flora aus der Hsiangchi Kohlen Serie in Westhupeh. Palaeontologia Sinica, New Series A, vol. 2, p. 1-71.

Takahasi, E., Uto, S., Mihara, A. and Takahasi, H., 1965: Palaeozoic and Mesozoic formations of the eastern and the southern parts of the Tabe Basin, Yamaguchi Prefecture. Science Reports of the Yamaguchi University, vol. 15, p. 33-49. (in Japanese)

Vakhrameev, V. A., 1991: Jurassic and Cretaceous floras and climates of the earth. Cambridge University Press, Cambridge.

Volynets, E. B., 1997: New data on the age of the Monakinsky sequence, Partizansk coal basin. Tikhookeanskaya Geologiya, vol. 16, p. 135-139. (in Russian)

Wu, S. Q., Ye, M. N. and Li, B. X., 1980: Upper Triassic and Lower and Middle Jurassic plants from the Hsiangchi Group, western Hubei. Memoir of Nanjing Institute of Geology and Palaeontology, Academia Sinica, vol. 14, p. 63-131. (in Chinese)

Yabe, A., Terada, K. and Sekido, S., 2003: The Tetori-type flora, revisited: a review. Memoir of the Fukui Prefectural Dinosaur Museum, vol. 2, p. 23-42.

Yamada, K., Niwa, S. and Kamata, M., 1989: Lithostratigraphy of the Mesozoic Tetori Group in the upper reaches of the Kuzuryu River, central Japan. Journal of the Geological Society of Japan, vol. 95, p. 391-403. (in Japanese)

Yamada, T. and Ohno, T., 2005: Revision of the stratigraphy of the Toyora and Toyonishi Groups in the Ouchi-Kikugawa area, Yamaguchi Prefecture, West Japan, Journal of the Geological Society of Japan, vol. 111, p. 389-403. 
Yamada, T., Yokoyama, K. and Kunugiza, K., 2005: Stratigraphic correlation of Tetori Group in Asuwa River area based on chemotaxonomy of clastic particles in sandstone. Abstracts of the 112th Annual Meeting of the Geological Society of Japan, p. 227. (in Japanese)

Yokoyama, M., 1889: Jurassic plants from Kaga, Hida, and Echizen. Journal of College of Science, Imperial University, Japan, vol. 3, p. 1-66, pls. 1-14.

Zeiller, R., 1903: Flore fossile des gites de charbon du Tonkin (Études des gîtes de minéraux de la France), Maison Quantin, Paris.

Zhou, Z., 1983: Early Liassic plants from southwest Hunan, China.
Palaeontologia Sinica, New Series A, no. 7.

Ziegler, A. M., Parrish, J. M., Yao, J., Gyllenhaal, E. D., Rowley, D. B., Parrish, J. T., Shangyou, N., Bekker, A. and Hulver, M. L., 1993: Early Mesozoic phytogeography and climate. Philosophical Transactions of the Royal Society of London, Series B, vol. 341, p. 297-305.

Ziegler, A. M., Rees, P. M., Rowley, D. B., Bekker, A., Qing, L. and Hulver, M. L., 1996: Mesozoic assembly of Asia: constraints from fossil floras, tectonics, and paleomagnetism. In, Yin, A. and Harrison, M. eds., The Tectonic Evolution of Asia, p. 371-400. Cambridge University Press, Cambridge. 